\title{
Constraints in Production, Consumption and Marketing of Fish in Selected Districts of North Karnataka, India
}

\author{
H. R. Harish Kumar ${ }^{\text {** }}$, B. R. Jamakhandi ${ }^{2}$ and G. K. Anil Kumar ${ }^{3}$ \\ ${ }^{1}$ Department of Agricultural Economics, ${ }^{3}$ Department of Animal Sciences \\ University of Agricultural Sciences, Dharwad, Karnataka-580005, India \\ *Corresponding author
}

Keywords

Competition,

Bargaining,

Storage,

Constraints,

Fingerlings

Article Info

Accepted:

15 December 2019

Available Online:

20 January 2020
A B S T R A C T

The present study was carried out in Dharwad and Belagavi districts of North Karnataka to study the constraints in production, consumption and marketing of fish. For this purpose, multistage random sampling procedure was adopted for the selection of the ultimate unit of samples. The data was collected from 60 selected fish farmers, 60 selected fish consumers and 30 market functionaries during the period 2018-19. Garrett's ranking technique was used to analyze the data. The results revealed that the lack of training facility, non-availability of quality fingerlings, water scarcity is some of the problems faced by the farmers in fish production. Market distances, price variation, non-availability of fresh fish were the major problems faced by the consumers of fish. Stiff competition, high bargaining, non-availability of proper storage facility are the major problems faced by the market functionaries in marketing of fish in the study area.

\section{Introduction}

Fish is an aquatic animal reared in both marine and fresh water. Fisheries are an important source of food, income, nutrition and livelihood for millions of people around the world. Fish plays a major role in human diet as they are rich in omega-3 fatty acids, amino acids, vitamins and trace elements. Consumption of fish provides many health benefits such as increase intelligence, healthy development of brain tissues and retina in children; lowers blood pressure, reduces blood clots, lowers blood fats and increases good cholesterol (Nashila and Sekharan, 2018). Fish consumption is also known to reduce the risk of delivering premature baby at the time of pregnancy, increase breast milk during lactation and strengthen the bones of mother (Nashila and Shekharan, 2018). 
India is the third largest fish producing and second largest aquaculture producing country in the world. Thriveni et al., (2018). India has good marine and inland water resources. India possess a coastline length of 8,118 kilometer, 2.02 million sq. $\mathrm{km}$ of Exclusive Economic Zone (EEZ), 0.53 Million Sq. $\mathrm{km}$ of continental shelf, 1537 fish landing centers and 3432 fishing villages India's Inland resources consists of 3.15 million hectare area under reservoirs, 2.36 million hectare area of tanks and ponds, 1.24 million hectare area of brackish water and 0.19 million hectare length of rivers and canals (Sree et al., 2016). The availability of these resources suggests huge scope for fisheries and aquaculture production in India.

The fish production in India has risen from 752 thousand tonnes in the year 1950 to 12,327 thousand tonnes in 2017 with a growth of 5.06 percent. Fisheries sector contributes 5.23 per cent to agriculture GDP and 0.91 per cent to overall GDP. This sector provides employment to 14 million people (www.indiastat.com). In 2017, the total fish production in India was 12,327 thousand tonnes with a share of 3,562 thousand tonnes from marine and 8,765 thousand tonnes of Inland fishery production. Among the states, Andhra Pradesh is the highest Inland fish producing state with a production of 2861 thousand tonnes and Gujarat is the highest marine fish producing state with a production of 708 thousand tonnes. The marketing of fish in India is dominated mainly by informal sector. Around 14 million people are involved in fish and fishery related activities and contribute to the livelihood of people who are economically underprivileged section of the society. Lack of infrastructure is one of the bottlenecks in the efficient marketing of fish in Indian states (Gawa et al., 2017).

Karnataka has a costal length of $300 \mathrm{Km}$. Surface water in Karnataka is available in the form of rivers, waterfalls, lakes, reservoirs, etc and has water potential of about $102 \mathrm{Km}$. In 2016, the total inland fish production in Karnataka was 1,58,568 Mts. Shivamogga, Mandya and Bellary are top three fish producing districts about 17,443 Mts, 12,924 Mts and 10,388 Mts respectively. Karnataka contributes about $4.64 \%$ to total fish production in India. In North Karnataka, Belagavi was the second highest (4,760 Mts) and Dharwad was the second lowest $(1,973$ Mts) in fish production (Anonymous, 2017).

\section{Materials and Methods}

The study was based on primary data and collected through personal interview method from fish farmers, fish consumers and market functionaries with the help of well-structured and pretested schedule exclusively designed for the study. Multistage random sampling was used for the selection of study area. In the first stage, Dharwad and Belagavi districts were selected purposively. In the second stage, three out of five taluks in Dharwad district and three out of ten taluks in Belagavi district were selected purposively. In the third stage, one village was selected randomly from each taluk. Totally, six villages were chosen. In the fourth stage, ten farmers from each sample village were selected randomly based on their use of fish production pond/tank.In order to analyse the constraints in fish consumption in Dharwad and Belagavi districts, one fish market from each taluk was selected randomly resulting in a total of six fish markets. From each fish market ten fish consumers and five market functionaries were selected randomly. Total sample consisted of 60 fish producers, 60 fish consumers and 30 market functionaries selected randomly from the study area. Thus, in all, the study sample consisted of 150 respondents.

Garrett's ranking technique was used to know the acceptance of respondents and constraints 
in production, consumption and marketing of fish. Basically it gives the change of orders of constraints and advantages into numerical scores. The major advantage of this technique as compared to simple frequency distribution is that the constraints and advantages are arranged based on their importance from the point of view of respondents. Hence, the same number of respondents on two or more constraints may have been given different rank (Kumar and Pandey, 1999).

Garrett's formula for converting ranks into per cent was given by,

Per cent position $=100 \times\left(\mathrm{R}_{\mathrm{ij}}-0.5\right) / \mathrm{N}_{\mathrm{j}}$ Where,

$\mathrm{R}_{\mathrm{ij}}=$ rank given for $\mathrm{i}^{\text {th }}$ factor by $\mathrm{j}^{\text {th }}$ individual $\mathrm{N}_{\mathrm{j}}=$ number of factors ranked by $\mathrm{j}^{\text {th }}$ individual

The percent position of each rank was converted into scores by referring tables given by Garrett and Woodsworth (1969).

\section{Results and Discussion}

Problems faced by the respondents during production, consumption and marketing of fish

Opinion survey was carried out to know the constraints faced by the respondents in the production, consumption and marketing of fish in the study area and the data was analyzed with the help of Garrett's ranking technique. During the survey, six problems were identified in fish production such as, lack of training facilities, non-availability of quality fingerlings, water scarcity, lack of institutional credit, natural predator problem and oxygen deficiency. With respect to fish consumption nine problems were identified like market distance, price variation, nonavailability of fresh fish, high price, price of substitutes, presence of spines/bone/fins, smell, religious issues and non-availability of preferred fish species. In addition, six difficulties related to fish marketing were documented such as stiff competition, high bargaining, non-availability of proper storage facility, high shop rent, non-availability of specific fish species, unsuitability of market yard. Constrains faced by the respondents were ranked according to the Garrett's score.

\section{Constraints faced by the farmers in fish production}

The problems in fish production expressed by farmers were ranked based on the results of Garrett ranking analysis and listed in Table 1. Out of six constraints faced by the farmers, majority (Garrets score 93.18) of the farmers expressed that the lack of training facility was the major problem. This was followed by non-availability of quality fingerlings (II), water scarcity (III), lack of institutional credit (IV), natural predator problem (V) and oxygen deficiency for fish (VI). Similar results were identified by Devi et al., (2014). The results from the study indicate that the expansion of inland fisheries with available farm ponds could be taken up as the farmers are interested in fish production provided some of the major constraints are overcome immediately. The extension personnel from the government agencies and Agricultural/Veterinary Universities should take the initiative in providing training for the scientific inland fish production. The government agencies should also make arrangements in supply of good quality fingerlings at subsidized rate. If the farmers take up fish production in their farm ponds, it will be an additional source of income for the farmers.

Constraints faced by the consumers in fish consumption

According to the perception of the fish consumers, the major problems faced in 
consumption of fish is presented in Table 2 . The results of the Garret ranking analysis on the constrains associated with consumptions of fish showed that among the nine identified constraints, market distance was ranked first with a highest Garrett score (79.16) followed by Price variation (59.08), non-availability of fresh fish (56.57), high price (56.04), price of substitutes (44.51), Presence of spines/bone/fins (42.31), smell (40.56), religious issues (36.96) and non-availability of preferred fish species (33.61).The results from our study indicate that the creation of infrastructure for fish marketing at locations accessible to the consumer could increase the demand for fish production. Also, regulation of price of the fishes could help increase the sale of fish and support fish production.

Table.1 Constraints faced by the sample fish farmers in production of fish

$$
(n=60)
$$

\begin{tabular}{|c|l|c|c|}
\hline Sl. & \multicolumn{1}{|c|}{ Constraints } & Garrett's Score & Rank \\
\hline No. & & & \\
\hline $\mathbf{1}$ & Lack of training facility & 93.18 & I \\
\hline $\mathbf{2}$ & Non availability of quality of fingerlings & 84.55 & II \\
\hline $\mathbf{3}$ & Water scarcity & 83.13 & III \\
\hline $\mathbf{4}$ & Lack of institutional credit & 64.52 & IV \\
\hline $\mathbf{5}$ & Natural predator problem & 50.38 & V \\
\hline $\mathbf{6}$ & Oxygen deficiency for fish & 48.84 & VI \\
\hline
\end{tabular}

Table.2 Constraints faced by the sample consumers in the consumption of fish $(\mathrm{n}=60)$

\begin{tabular}{|c|l|c|c|}
\hline SI. & \multicolumn{1}{|c|}{ Constraints } & Garrett's Score & Rank \\
\hline No. & & & \\
\hline $\mathbf{1}$ & Market distance & 68.57 & I \\
\hline $\mathbf{2}$ & Price variation & 59.08 & II \\
\hline $\mathbf{3}$ & Non-availability of fresh fish & 56.57 & III \\
\hline $\mathbf{4}$ & High price & 56.04 & IV \\
\hline $\mathbf{5}$ & Price of Substitutes & 44.51 & V \\
\hline $\mathbf{6}$ & Presence of spines/bone/fins & 42.31 & VI \\
\hline $\mathbf{7}$ & Smell & 40.56 & VII \\
\hline $\mathbf{8}$ & Religious issue & 36.96 & VIII \\
\hline $\mathbf{9}$ & Non-availability of preferred fish species & 33.61 & IX \\
\hline
\end{tabular}


Table.3 Constraints faced by the market intermediaries in marketing of fish

\begin{tabular}{|r|l|c|c|}
\hline SI. & \multicolumn{1}{|c}{ Constraints } & Garret Score & Rank \\
No. & & & \\
\hline $\mathbf{1}$ & Stiff competition & 79.16 & I \\
\hline $\mathbf{2}$ & High bargaining & 75.00 & II \\
\hline $\mathbf{3}$ & Non-availability of proper storage facility & 67.50 & III \\
\hline $\mathbf{4}$ & High shop rent & 64.00 & IV \\
\hline $\mathbf{5}$ & Non-availability of specific fish species & 44.00 & V \\
\hline $\mathbf{6}$ & Unsuitability of Market yard & 43.33 & VI \\
\hline
\end{tabular}

\section{Constraints faced by the market functionaries in fish marketing}

The major marketing constraints faced by the market intermediaries in the study area presented in Table 3. The results of the Garrett analysis indicated that the stiff competition was the major problem faced during marketing. This was followed by high bargaining (II), Non-availability of proper storage facility (III), high shop rent (IV), nonavailability of specific fish species (V) and unsuitability of market yard (VI).Vinay et al., (2015) reported similar results. The results show that creation of proper infrastructure would be paramount for success of businesses related to marketing of fishes not only for the consumers as discussed earlier but also for the market functionaries. Initiatives should be made for the supply of different variety of fishes to these places at reasonable price so that the current demand for the same could be met and open up avenues for expanding the markets so that it is beneficial to both the consumer and the market functionaries.

It is concluded that fishing could be one of the major subsidiary occupations for farmers as it adds to the additional income to the farmers that have farm ponds in their agricultural lands. This paper analyzed the production, consumption and marketing of fish in Dharwad and Belagavi districts of North Karnataka. The study revealed that lack of training facility is the major problem for farmers in fish production, for fish production training is necessary for farmers in feeding, harvesting and management it increases production. Creation of proper infrastructure at the fish markets is likely to benefit the consumers and the market functionaries related to fish production.

\section{Acknowledgements}

The authors acknowledge the financial support received by the first author from the University of Agricultural Sciences, Dharwad for conducting this study.

\section{References}

Anonymous, 2017, Inland fish production, Government of Karnataka, 2017-18: pp. $1-2$

Devi, S.Z., Singh, N.R., Anandkumar, N and Laxmith, 2014, Fish production in Manipur- An economic analysis. $J$. Crop Weed., 10 (2) 19-23.

Garrett, H.E and Woodworth, R.S 1969, Statistics in psychology and education. Bombay: Vakils, Feffer and Simons 
Pvt. Ltd.

Gawa, S., Kumar, N.R., Mahida, N., Hatte, V.M and Vinay, A 2017, A study on marketing cost, margin, price spread and efficiency of fish marketing in unregulated fish markets in Srinagar, Jammu and Kashmir. Int. J. Pure App. Biosci., 5 (4): 300-308.

Kumar, A and Pandey, 1999, Application of garret ranking technique: practical approach. Int. J. Library Information Stud., 6 (3): 135-140.

Nashila, R and Shekaran, M. 2018, Consumer behavior about seafood and seafood safety. International Journal of Current Advanced Research., 7(1): 8727-8736.
Sree, P.V. and VenkatRao, P. 2016, Importance of marine fisheries in Indian economy. Int. J. Appl. Sci. Eng. Manag., 2(10): 68-83.

Thriveni, K., Sudhakar, D., Dhanapal, K. and Raja, K.M., 2018, Fish consumption practices in Nellore, Andhra Pradesh. Int. J. Agril. Sci., 10 (6): 5421-5423.

Vinay M.H., Swadesh, P., Kumar, N.R., Vinay,A. ansStanzin, G., 2015, Market structure and constraint analysis of fish markets in Nanded district of Maharashtra. Indian J. Agril. Mktg., 29(2): 68-83.

www.indiastat.com

\section{How to cite this article:}

Harish Kumar, H. R., B. R. Jamakhandi and Anil Kumar, G. K. 2020. Constraints in Production, Consumption and Marketing of Fish in Selected Districts of North Karnataka, India. Int.J.Curr.Microbiol.App.Sci. 9(01): 1957-1962.

doi: https://doi.org/10.20546/ijcmas.2020.901.220 